\title{
RESISTÊNCIA CARNAVALESCA AO ESPETÁCULO GLOBAL
}

\section{RESUMO}

Este artigo apresenta uma proposta de aplicação crítica pós-moderna do "espetáculo" de Debord e do "carnaval" de Bakhtin às encenações que têm acontecido nas ruas das cidades, nos campi de universidades e na Internet resistindo à nova economia globalizada. Na última década, a Administração Pública passou por uma virada pós-moderna, ficando presa às encenações conflitantes de um espetáculo corporativo orquestrado pela mídia e ao carnaval de resistência do discurso de globalização. Pretende-se neste artigo teorizar a interação do espetáculo e do carnaval como construções teatrais de poder e resistência empresarial e estatal. São analisados o crescimento do espetáculo da indústria de monitoramento, que atesta códigos corporativos de conduta em narrativas de progresso, e os carnavais anti-sweatshop ${ }^{1}$ e anti-globalização, que desempenham um roteiro de entrega no teatro de rua, nos shows de moda anti-sweatshop e no ativismo cibernético.

\section{David M. Boje}

Ph.D. em administração de empresas e Professor de gestão na New México State University.

E-mail: dboje@nmsu.edu

\begin{abstract}
I propose a critical postmodern application of Debord's Spectacle and the carnivalesque of Bakhtin to the theatrics I see happening in city streets, on college campuses, and Internet resisting the new globalized economy. In the past decade Public Administration has experienced the postmodern turn, becoming caught in the conflicting theatrics of corporate-mediatized spectacle and the carnival of resistance to globalization discourse. My contribution is to theorize the interplay of spectacle and carnival on the global stage as theatrical constructions of corporate and state power and resistance. I analyze growth of the spectacle of the monitoring industry that attests corporate codes of conducts in narratives of progress, while the anti-sweatshop and anti-globalization carnivals perform a devolution script in street theater, anti-sweat fashion shows, and cyber-activism.
\end{abstract}

PALAVRAS-CHAVE Administração Pública, globalização, sweatshop, mídia, ativismo.

KEY WORDS Public Administration, globalization, sweatshop, media, activism. 


\section{INTRODUÇÃo}

Bem-vindo(a) ao nosso show de moda sweatshop, uma combinação de teatro político e comédia educacional. Hoje, vocês verão nossas modelos mostrando algumas das últimas modas vindas da Ásia, América Latina, Estados Unidos, Austrália e Canadá.

Ao invés de super-modelos em vestidos de seda curtíssimos custando milhares de dólares, essas vestimentas são feitas em sweatshops, vendidas em universidades, em lojas de roupas ou no Wal-Mart mais próximo. Em tais shows, encenados em universidades, nas ruas das cidades e em shopping-centers, modelos entram e caminham na passarela vestindo as últimas novidades da Nike, Disney, Guess, Gap, Van Heusen, Tommy Hilfiger e Wal-Mart enquanto locutores comentam sobre salários miseráveis e condições de trabalho abusivas. A maioria das universidades americanas já abrigou shows de moda sweatshop similares destacando as condições de trabalho na indústria de roupas não somente na América Latina e Ásia, mas em cidades metropolitanas. A Maquiladora Solidarity Network (2001a) fornece idéias para roteiros de shows de moda:

"Nossa próxima modelo, Sheila, está vestindo jeans apertadíssimos da Guess feitos no México. A Sheila não parece ótima? A imagem do logotipo da Guess é quente e sexy... Na verdade, 'quente e sexista' é provavelmente uma descrição melhor das condições de trabalho das mulheres costurando produtos da Guess. Quente como as sweatshops e sexistas como seus supervisores. Uma investigação de quatro fábricas da Guess no México em 1998 descobriu evidências de horas-extras forçadas, violações de leis sobre o trabalho infantil, condições perigosas de trabalho, discriminação contra mulheres grávidas, pobreza, repressão e medo. Obrigado, Sheila." (MSN, 2001a).

O foco aqui é no que Bakhtin e Kristeva chamariam de "carnaval", ou seja, o uso de teatro para parodiar e resistir a espetáculos de hegemonia corporativa global, misturando sátira ultrajante, música popular, modelos e pedagogia crítica para problematizar a globalização e o livre comércio como ideologias reinventadas da colonização e do racismo global no século XXI. O espetáculo é cada vez mais uma performance orquestrada por empresas, uma exposição destinada a persuadir as massas de espectadores de que as empresas globais implementaram códigos morais de conduta e, portanto, merecem a confiança pública.

A tese é de que muito do protesto global é carnaval. É possível observar isso no confronto da polícia, que vestida de máscaras de Vader e aparatos de proteção, enfrentava os 400 mil ativistas da World Trade Organization (WTO). Os homens, vestiam cascos de tartaruga-marinha, e as mulheres, saltitavam nuas com escritos "antes nuas que com Nike" ou "sem-BGH" rabiscados em seus seios e costas, além de levarem bonecos gigantes e camisinhas flutuantes do tamanho de dirigíveis com os dizeres "pratique comércio seguro".

Para Bakhtin (1973), o carnaval é "aquele peculiar humor popular que sempre existiu e que nunca se uniu com a cultura oficial das classes dominantes." As encenações de rua do protesto da WTO em Seattle, assim como o movimento anti-sweatshop, tornaram-se uma paródia carnavalesca do poder empresarial. $\mathrm{Na}$ erosão do Estado Nacional como um personagem global, o Estado Corporativo emergiu como uma nova estrela do teatro global, mas uma estrela que é tratada como vilão por ativistas em produções teatrais off-Broadway (Saner, 1999) que rebeldemente reinterpretam a experiência de consumidores colocando roupas em encenações roteirizadas para aumentar a conscientização.

O objetivo do presente artigo é examinar o ativismo carnavalesco e sua relação com o espetáculo global.

Foucault (1979) afirma que a resistência acompanha o poder. Aqui, é importante observar como o carnaval opõe-se não a Las Vegas, Disney ou Hollywood, mas a espetáculos que legitimam o "livre comércio" e a globalização. A "dysneyficação" e "lasvegatização" reformam locais de verdade, como Paris, NY, Roma, Egito e Veneza, dando experiências esterilizadas, estilizadas e virtuais, porém fragmentadas a seus visitantes, que acabam dizendo que assim é "melhor que a vida real", porque é "mais seguro", "mais limpo", "mais rápido" ou "mais fácil de caminhar". Com isso, consumidores dirigem-se para as cidades de verdade e têm a expectativa de que elas sejam como Las Vegas ou Disney, e eventualmente elas serão. Essa transformação em simulações cada vez mais virtuais, e digitais, exige uma teorização administrativa radical situada na cultura pós-moderna emergente. Tal cultura inclui a fragmentação corporativa de nossas identidades por meio dos logotipos de empresas, "lasvegatização" e "dysneyficação" de nosso lazer e "mcdonaldização" de nosso trabalho, e a grande rede de diversos movimentos sociais e grupos de protesto tornamse forças de oposição ao capitalismo global e à nossa própria comercialização, usando o teatro digital e de rua.

Assim, após a introdução de alguns conceitos fundamentais, busca-se traçar a relação entre essas forças de oposição, manifestadas pelo carnaval e pelo espetáculo, e suas implicações para a Administração Pública. 


\section{Definindo termos}

A teoria administrativa e sua aplicação prática estão espalhadas entre o espetáculo do capitalismo global orquestrado pela mídia - que testemunhamos em nossas telas de TV - e as novas maneiras de participação do cidadão no carnaval em nossa era de cultura pós-moderna. De acordo com a crítica de Bogason (1999), a última década assistiu a um aumento dramático na publicação de trabalhos sobre teoria pós-moderna na Administração Pública. Essa cultura desafia noções tradicionais de democracia, cidadania e Administração Pública. Esta, por sua vez, é colonizada pelo capitalismo corporativo, enquanto tem de competir com a fragmentação da identidade e formas emergentes de cultura pósmoderna que protestam contra a globalização. Ao mesmo tempo, o trabalho de teoria pós-moderna da Administração Pública é criticado por negligenciar direitos humanos, igualdade e justiça social (Ventriss, 1998), por propor um pensamento "pós-crítico" que cria o assunto como texto e por ignorar todas as grandes narrativas, negligenciando, portanto, também as condições materiais da inerente economia política defendida pela teoria crítica (Carr, 1996; Zanetti e Carr, 1997, 1999). Porém, existem variações na teoria pós-moderna que podem oferecer potencial emancipatório, sem ignorar todas as grandes narrativas, e que são atentas às condições materiais do trabalho e da ecologia.

Em vez de colocar a teoria pós-moderna como responsável por tudo que há de errado na ordem mundial ("dysneyficação", "lasvegatização", fragmentação), é preferível desenvolver uma discussão "crítica pós-moderna" do discurso global. Esta é definida como coração da teoria crítica, do pós-colonialismo, da pedagogia crítica e da teoria pós-moderna (Boje, 2001c). Discorda-se de outras teorias pós-modernas que procuram se limitar ao que é "construído socialmente" como apenas "texto" sem contexto, ou que são incapazes de discurso ético. Prefere-se seguir Best e Kellner (1997) e combinar o foco de Marx nas condições materiais com a Society of the spectacle de Debord (1967), ao invés de focar na hiperrealidade de Baudrillard ou ignorar todas as grandes narrativas como Lyotard.

Debord (1967) usou a análise da produção de Marx em seu estudo relacionando-a à acumulação e ao consumo de espetáculos. O espetáculo é muitas vezes uma performance teatral que legitima, racionaliza e esconde o consumo e a produção violenta (Boje, 2001a; Best e Kellner, 1997, 2000; Firat e Dholakia, 1998). Espetáculos teatrais podem ser uma forma benigna de prática e atuação. Eventos de gala com fantasias, arte, histórias de sucesso, prêmios para equipes e presença de celebridades para apresentar novos produtos simbolizam uma iniciativa de mudança ou colocam o holofote em atos positivos do poder corporativo.

A teoria crítica pós-moderna, por contraste, entende que existe uma condição material, muitas vezes violenta, estimulada pelo espetáculo da mídia. Todos são responsáveis eticamente por minimizar a violência do espetáculo retomando o discurso boca-a-boca, não participando da eco-destruição sem pensar e resistindo por meio do uso do carnaval como uma maneira festiva de estar no mundo. Usando métodos de análise de textos, teoria de espetáculos, discurso e análise narrativa, acredita-se ser possível decodificar as camadas do espetáculo de relações públicas que endeusam empresas virtuais globais como autoras do progresso e da evolução. O espetáculo também distancia empresas transnacionais da responsabilidade sobre suas dispersas cadeias de suprimento, nas quais as condições particularmente exploradoras parecem florescer em um reaparecimento de sweatshops, cuja descrição rivaliza a de Marx (1867) de capital de trabalho "suado". Empresas virtuais, como Nike, Adidas, Reebok, Gap e Guess, mantêm P\&D e funções de marketing enquanto fornecem ao Terceiro Mundo.

Recentemente, a responsabilidade corporativa tem contratado empresas de consultoria como Global Alliance for Workers and Communities (GA), empresas de contabilidade como PricewaterhouseCoopers (PwC) e grupos de comércio como Fair Labor Association (FLA) e Worldwide Responsible Apprel Production (WRAP) para monitorar o chão de fábrica. A $\mathrm{PwC}$ auditorou, em 1999, os códigos de conduta complacente de 6 mil fábricas contratadas pela Nike, Disney, Wal-Mart, Gap e outras multinacionais.

Cada vez mais são o foco dos carnavais de resistência as corporações virtuais e as empresas contratadas que monitoram suas fábricas. Somos testemunhas de um bloqueio de cultura pós-moderna, shows de moda anti-sweat e, mais recentemente, atos virtuais de desobediência cibernética. A maioria adota ações não-violentas para promover um capitalismo menos violento que o atual, enquanto nos alertam e conscientizam sobre nosso consumo e trabalho ou relacionamento instrumental com animais, plantas, humanos e o mundo macrobiótico.

A teoria crítica pós-moderna contribui para a Administração Pública ao nutrir e retomar o discurso público e democrático de sua colonização corporativa. Perspectivas críticas pós-modernas dão espaço para ações de solidariedade e de desobediência civil radicais não-violentas entre contra-públicos fragmentados e comunida- 
des subalternas. Isto é, fazer algo sobre a falta de voz dos trabalhadores explorados, para que eles possam se unir aos cidadãos e estudantes, tomando as ruas, protestando contra o impacto da globalização corporativa na ecologia. Isso pode até torná-los teóricos ativistas mais radicais, que enxergam o que há por baixo dos espetáculos de progresso e do trabalho de conhecimento da realidade corporativa virtual. Uma tarefa relacionada à teoria crítica pós-moderna é, com espetáculos narrativos defensivos, enfraquecer a cumplicidade da Administração Pública (e de outros campos como a Administração de Empresas) ao expor políticas econômicas, étnicas e sexuais e práticas administrativas opressivas, enquanto abre espaços para a emergência de um novo discurso democrático.

\section{Administração Pública pós-moderna}

Esta não planeja ser uma análise completa (o que seria uma tarefa para toda uma edição). Ao invés disso, destaca-se alguns pontos principais na virada pós-moderna da Administração Pública. Hummel (1989) e Dennard (1989) estavam entre os primeiros a usar o termo "pós-moderno" em conjunção à Administração Pública. Hummel observou a organização pós-moderna, enquanto Dennard escreveu sobre humanismo radical em uma narrativa satírica da teoria de Burrell e Morgan como se fosse a história infantil de Cachinhos dourados e os três ursinhos. Marshal e White (1990) introduziram o pósmodernismo como um método para a comunidade da Administração Pública em sua análise desconstrutivista do Manifesto de Blacksburg (constitucionalismo) - uma reação à metáfora do mercado dominando a Administração Pública. White (1992), por sua vez, reconhece a virada narrativa e afirma que como o que sabemos é vestido em histórias; a ciência administrativa é apenas outra narrativa. White e McSwain (1993) examinaram as possibilidades da semiótica e do pós-modernismo na Administração Pública norte-americana afastarem-se de teorias que se dizem verdadeiras e de especialistas que receitam o que é melhor para as comunidades. Fox e Miller (1993) teorizaram a Administração Pública pósmoderna como uma mudança de centrípeta para centrífuga, centralização para fragmentação, unidades em comum para incomensurabilidade, diferença ao invés de semelhança, universal para hiper-pluralismos, fragmentação ao invés de unidades generalizadas de análise, de Newton para a física quântica de Heisenberg, e da teoria causal para a análise imprevisível do microcosmos. Farmer (1994) observa os aspectos da construção social da Administração Pública, questionando se a eficiência semiótica do movimento de reinvenção governamental acaba por privilegiar o controle.

Livros de Fox e Miller $(1995,1997)$ focam a necessidade de teoria discursiva na Administração Pública pós-moderna como alternativa para o modelo inputoutput-feedback. A Linguagem da Administração Pública de Farmer (1995) observa textos usando uma técnica de Derrida, teorizando em um círculo hermenêutico a desterritorialização de Deleuze e Guattari e os limites das grandes narrativas - como eficiência taylorista, especialização e aspirações à ciência da Administração Pública. O foco é em vozes marginalizadas, em Administração Pública para minorias, mulheres, sexualidades policiadas e os economicamente colonizados. Farmer (1998) continuou esse foco e observa uma escuta radical ao "Outro" ${ }^{2}$ que poderia liberar vozes marginalizadas. O livro crítico de Harmon (1995) foca a representação da Administração Pública sob condições do mercado capitalista como agência, sendo que a responsabilidade moral, por exemplo, é transferida do Estado e de seus servidores públicos burocráticos para o mercado.

\section{Teoria crítica pós-moderna e Administração Pública}

Uma análise crítica pós-moderna de espetáculo e carnaval é, compatível com muito do trabalho teórico que vem sendo feito em Administração Pública. Fox e Miller (1993, 1995), por exemplo, enxergam o consumismo induzido pela mídia e a fragmentação "neo-tribal" da sociedade, que vê consumidores identificando-se e se definindo por intermédio de logotipos e slogans da Nike e de outras empresas e imagens flutuantes na mídia. Escritos críticos acadêmicos sobre a Nike, Disney, Monsanto e outras empresas são apenas o começo. Stabile (2000), por exemplo, argumenta:

"Similarmente, se arranharmos um pouco a superfície da fachada da Nike, poderemos ver como os códigos de conduta tão valorizados pela cultura corporativa são deslocados para grupos de pessoas que não têm os meios econômicos para consegui-los legalmente mas são de qualquer maneira tidos como responsáveis pela criação de tais códigos e desejos."

Na Administração Pública, os trabalhos de Zanetti e Carr, em uma teoria crítica, por exemplo, focam o que Habermas chama de grupos "não-verdadeiros" de discurso que degradam a esfera popular. Vê-se muito do discurso corporativo como não-verdadeiro. O consumismo induzido pela mídia reduz indivíduos a tipos de identidade de consumidor que não mais enxergam por meio de código / superfície a "realidade" das 
condições de trabalho. Recentemente, muito mais pessoas que pensam estar cientes do trabalho alienado, da falta de vozes no comércio global ou de propagandas greenwash ${ }^{3}$ estão tomando as ruas ou a Internet para participarem de forma diferente. Entretanto, essa conscientização é contraposta por desculpas acadêmicas patrocinadas por empresas e pelo controle da mídia.

Em resumo, o presente artigo usa teoria crítica pósmoderna para explorar uma ligação na relação entre espetáculo, carnaval e Administração Pública. Teoriza-se a prática administrativa nas contra-forças do espetáculo e da resistência carnavalesca. A contribuição para a Administração Pública é evidenciar a relação do espetáculo corporativo global com teatros mais carnavalescos de resistência dos cidadãos. Foca-se no movimento antisweatshop e na posição de limite da Administração Pública. São feitas breves análises de espetáculo e carnaval, depois apresentando diversas aplicações e ilustrando suas relações dinâmicas.

\section{ESPETÁCULO}

O espetáculo é baseado no trabalho de Debord (1967), Society of the spectacle, que tem algo importante a dizer sobre como espetáculos de produção e consumo relacionam-se com a Administração Pública, isto é, relata o por vezes violento e opressivo controle social que se mascara como uma celebração da melhora ao reciclar pseudo-reformas, falsos desejos, e visões seletivas de evolução progressiva, nunca regressão (Boje, 2001a). Espetáculo é uma narrativa e uma performance teatral que legitima, racionaliza e camufla a produção e o consumo violento. O espetáculo é mais presente e dominante que o carnaval. "Em todas suas formas específicas, como informação ou propaganda, como publicidade ou consumo de entretenimento direto, o espetáculo é o modelo presente da vida socialmente dominante." (Debord, 1967).

O espetáculo pode ser a total manipulação de processos criadores de significados por intermédio de eventos teatrais para servir à produção de poder e às necessidades gerenciais com o objetivo de controlar e criar uma boa história quando confrontado com más notícias. O espetáculo é altamente instrumental - a produção de um evento de gala com fantasias, arte, histórias de sucesso, prêmios e presença de celebridades que apresentam novos produtos - e simboliza uma iniciativa de mudança ou coloca o holofote em atos positivos do poder corporativo (exemplo: serviço comunitário). Por vezes, esses espetáculos celebram a benevolência e o progresso do poder com encenações e, outras vezes, encenam o teatro que leva a progressos tecnológicos e humanísticos. Apesar do trabalho seminal de Debord (1967), e da associação do movimento situacionista à teoria marxista, as implicações radicais de espetáculos de produção e consumo ainda precisam ser reconhecidas na teoria e na prática da Administração Pública. Na virada pós-moderna (Best e Kellner, 1991, 1997), o espetáculo é endêmico para o exercício do poder corporativo.

A seguir, pode-se observar vários instantes em que o espetáculo enfrenta resistência por parte do carnaval, primeiramente pelo monitoramento dos códigos das sweatshops, depois pelos shows de moda sweatshop e, finalmente, pelas novas e digitalizadas formas de espetáculo e carnaval.

\section{CARNAVAL}

O carnaval é um teatro de protesto e loucura que busca consertar a separação e alienação sentidas. É um chamado à libertação do poder corporativo, um grito de desconforto e repressão misturado com risos e exibições humorísticas que procura levar o poder estatal e corporativo a conscientizar-se da jaula psíquica do trabalho e da vida consumista. No teatro carnavalesco pré-moderno (Bakhtin, 1981), os nobres e clérigos eram odiados, degradados e ridicularizados por meio de vulgaridades, farsas, palhaçadas e grosserias. Na Festa dos Tolos, a classe baixa medieval ironizava e degradava a vida oficial dos nobres e do clero. No carnaval, as classes sociais e a distinção entre os sexos eram ignoradas. Rapazes vestiam-se de meninas, meninas de rapazes. Pessoas usavam máscaras grotescas e fantasias com barrigas, seios e nádegas gigantes. As encenações incluíam imitações farsescas de nascimentos e cópulas. Paródias de rituais da cultura oficial da Igreja e da nobreza eram comuns.

"Carnaval não é um espetáculo visto pelas pessoas; elas moram dentro dele e todos participam porque a própria idéia é englobar todas as pessoas. Enquanto dura o carnaval, não existe outra vida fora dele. Durante o tempo do carnaval, a vida é sujeita apenas às suas leis, ou seja, às leis de sua própria liberdade" (Bakhtin, 1981). O carnaval manifesta suas encenações a nosso redor enquanto figuras autoritárias e normas de comportamento que guiam nossa socialização são questionadas e suas estruturas rígidas tornam-se problemáticas (Mueller, 2000). O carnaval contemporâneo é mais controlado, um teatro mais seguro que o da Idade Média. O carna- 
valesco tem quatro temas: a platéia tumultuada, o mundo virado de ponta cabeça, a máscara cômica e o corpo grotesco. O carnaval contemporâneo é uma expressão polifônica daqueles sem poder, por vezes sancionado por aqueles no poder como uma maneira de acalmar os ânimos.

Aqui e ali pode-se observar brevemente o carnaval de resistência ao capitalismo global. Em campi de universidades, shows de modas e sit-ins ${ }^{4}$, são maneiras dos estudantes negociarem com os administradores códigos universitários de conduta, exigindo um melhor monitoramento sobre os contratos de roupas das universidades. Preocupados com notícias de abusos de direitos humanos existentes em fábricas de roupas, estudantes e professores por todo os EUA estão fazendo uma campanha para monitorar as condições de trabalho em que são feitas as camisetas, os chapéus e as camisas que os estudantes usam, para terem certeza que nenhuma delas está sendo feita em sweatshops. A United Students Against Sweatshops (USAS) é um movimento nacional de estudantes que possui sedes em mais de $150 \mathrm{campi}$ por todo os EUA; os campi do Canadá, Reino Unido e Austrália também possuem movimentos semelhantes. Protestos, shows de corte e costura e shows de moda sweatshop estão entre as encenações carnavalescas usadas para pressionar os administradores públicos das cidades e universidades a adotar códigos mais rígidos de conduta. Por exemplo, no dia anterior ao começo da conferência provincial da University of Toronto sobre sweatshops e universidades, os administradores da Universidade disseram aos estudantes em um encontro a portas fechadas que iriam "apagar a lousa" e criar um novo código de conduta em relação a que tipos de vestimentas poderiam ter o logotipo da universidade. Em Toronto, por exemplo, já aconteceram diversos shows de moda sweatshop protestando contra o fato da Nike ter negado a utilização de trabalhadores que recebem salários miseráveis para cortar, colar e costurar seus produtos.

É verdade que os protestos em universidades são muito poucos, e não estão mudando drasticamente os hábitos de consumidores que são induzidos pelas propagandas a serem superestrelas como Michael Jordan e Tiger Woods. Na maioria das universidades, quase nada é feito em relação ao abuso dos direitos humanos. Como nos dias de protestos contra a guerra do Vietnã, a maioria dos estudantes e professores não está protestando. A hipótese é de que o carnaval, na maneira como é definido por Bakhtin, será sempre marginal em sua própria maneira; ele é reacionário. E de algum modo é um protesto que é cuidadosamente controlado por interesses corporativos e estatais. Quando há um protesto, ele precisa ser em uma área específica e é necessário que se tenha permissão para protestar.

$\mathrm{Na}$ New Mexico State University, sempre atrás dos tempos, todos os protestos são limitados a áreas específicas de "liberdade de expressão", que são situadas em locais distantes das principais calçadas e áreas da comunidade. Estudantes e membros do corpo docente revoltaram-se, e até foram presos, lutando para tirar os protestos das áreas marginais e colocá-las dentro do campus. Entretanto, o controle ainda está com aqueles no poder e o trabalho de muitos administradores é evitar que o carnaval entre dentro da vida no campus. Busca-se, utilizando-se os exemplos a seguir, mostrar a relação entre carnaval e encenações teatrais em suas montagens e direção.

\section{Carnaval e monitoramento}

Somos espectadores de um espetáculo global visto à distância, dependemos do testemunho de monitores de conduta de trabalho em terras estrangeiras, olhamos e mudamos de canal entre esses relatos em algum tipo de monitor eletrônico. No começo da década de 1990, diversos escândalos ferveram a imaginação de legisladores, administradores públicos e consumidores. Do dia para a noite, a indústria de monitoramento nasceu enquanto 50 mil fábricas de roupas eram inspecionadas para que pudessem manter seus contratos com corporações globais que estavam sendo questionadas pelo governo, por uma minoria de acionistas e por alguns consumidores. Em quase uma década, esse monitoramento tornou-se uma indústria de consultorias e programas de certificação por grupos industriais, e já existem propostas para formar agências transorganizacionais supermonitoras. Seguindo o exemplo da Apparel Industry Partnership (AIP), a Collegiate Licensing Company (CLC) e as instituições por ela representadas criaram um código de conduta para seus licenciados. Outros grupos de monitoramento incluem a International Apparel Federation e a American Apparel Manufacturers Association, ambos os grupos estão explorando um sistema de monitoramento e certificação para seus membros.

O monitoramento pode se tornar uma ciência de lixo e nada mais que relações públicas pagas. Dessa maneira, torna-se um espetáculo de manipulação de processos, que por sua vez criam significados por intermédio de eventos encenados teatralmente servindo assim à produção de poder e às necessidades gerenciais para controlar e criar uma boa história se colocados face à 
notícias ruins ou escandalosas. O monitoramento é uma indústria bilionária - a Nike contribuiu US\$ 7,6 milhões para dois estudos - que inclui consultores caríssimos como a Global Alliance, consultorias como a PricewaterhouseCoopers - contadores agora auditorando códigos de direitos humanos e a FLA - que "certifica" consultores-monitores, como a Verité (2001), que serão contratados por essas corporações.

O teatro de rua do protesto na WTO, os sit-ins em escritórios de administração das universidades e os boicotes à Footlocker, Niketown, Gap, Wal-Mart e lojas de mercadorias da Disney são exemplos de resistências carnavalescas ao espetáculo do capitalismo pós-industrial e seu casamento com o consumismo pós-moderno. Esses carnavais feitos por estudantes, trabalhadores, ambientalistas, sindicalistas e ativistas também parodiam afirmações feitas por monitores de empresas e consultores como Fair Labor Association (FLA), PricewaterhouseCoopers (PwC) e Global Alliance (GA).

Os códigos de conduta universitários, corporativos e industriais não operam sem ambigüidade; as dinâmicas cada vez mais atraem e seduzem a Administração Pública a ter um papel de juiz nas disputas entre os grupos monitores corporativos como a FLA - e grupos estudantis como o Workers Rights Consortium (WRC). Administradores de universidades e idealizadores de políticas públicas são chamados a escolher entre as maneiras de monitoramento da FLA e da WRC.

A FLA, de acordo com ativistas, tem um código de conduta muito fraco que não inclui fundamentos como direitos da mulher, salários ou monitoramento independente. A United Students Against Sweatshops (USAS) e outras organizações estudantis lançaram o Workers Rights Consortium (WRC). A USAS está pedindo para todos os campi usarem a WRC como uma alternativa à FLA; a WRC sugere: monitoramento local por organizações religiosas e organizações não-governamentais (ONGs), que sejam pagos salários aos monitores e que seja dado um papel mais forte para a monitoração independente. A USAS e muitos outros grupos alegam que, com a globalização, houve um aumento da produção sweatshop de Bangladesh ao Brasil. Os trabalhadores envolvidos, em sua maioria mulheres do Terceiro Mundo, têm se juntado aos estudantes e trabalhadores na luta para aumentar salários, melhorar as condições de trabalho e promover a barganha coletiva.

Um novo papel da Administração Pública é desmonopolizar e descolonizar as esferas do discurso público dominadas pelas corporações e aos poucos apropriadas pelo espetáculo corporativo. Escritores da área, como Jon e Campodoncio (1998), argumentam que a globalização tenta as nações do Terceiro Mundo a criar exceções regulamentais que forçam os ecossistemas, assim como estressam o trabalho humano ao máximo para diminuir as pressões por salários e benefícios. O espetáculo serve para manter o monitoramento regulador, judicial e legislativo da indústria de roupas sob seu controle. Na prática, uma opção é que os administradores públicos sejam críticos do espetáculo onde estão, que vejam as ondas carnavalescas de protesto como uma maneira de balancear os espetáculos de ganância e pilhagem que continuam sem serem punidos devido à propaganda registrada pelo controle da mídia.

Tentativas para controlar o consumidor pós-moderno e o vínculo das cadeias de suprimentos pós-industriais com as sweatshops são difíceis de implementar. Por exemplo, a WRAP conduz um programa global de certificação, analisando relatórios de monitoramento de fábricas feitos por empresas e dando um selo de aprovação às "boas fábricas". Recentemente a WRAP pediu a três firmas de monitoramento - PricewaterhouseCoopers, Intertek Testing Services e CSCC - que fizessem auditoria em dezenas de países em todo o mundo, mesmo considerando que o diretor da WRAP, Otto Reich, esteve envolvido nos anos 1980 na conspiração Irã-contras, e a própria WRAP é amplamente vista como um órgão que desvia o monitoramento ativista e governamental do comportamento corporativo (Maquiladora Solidarity Network, 2001b).

O administrador público fica preso, assim, à simulação, à hiper-realidade e à simplificação e colonização do monitoramento: uma vez parte da esfera pública, é agora província dos agentes do setor privado - por exemplo, FLA, GA e WRAP. Códigos de conduta operam de maneira ambígua. Mesmo assim, cada vez mais o papel da Administração Pública é ser o juiz em disputas entre a FLA e a WRC, por exemplo. O interesse público - códigos morais de trabalho - entra em conflito com interesses corporativos - maximização do lucro por meio da exploração do trabalho. O administrador público não pode mais monitorar diretamente, já que está preso às condições da esfera pública. O perigo é que o interesse público una-se ao interesse corporativo, com cada vez mais cidadãos perdendo seu poder de protesto.

Sem o envolvimento da Administração Pública, o perigo é que os interesses corporativos apropriem-se dos interesses públicos, por vezes resultando nos chamados programas corporativos de bem-estar. Alegando falta de poder de protesto, cidadãos reinventam formas de re- 
sistência carnavalesca para recuperar suas vozes. O poder corporativo reage a essas formas de resistência ao investir milhões de dólares em uma indústria de monitoramento que pode produzir o que muitos estudiosos críticos pós-modernos chamariam de "ciência do lixo", isto é, relatórios comprados por empresas que legitimam interesses corporativos ao aplicar uma ciência que não conseguiria validação ou confiabilidade para ser publicada em periódicos especializados.

\section{Retórica de motivos}

O argumento aqui é que estamos sendo confrontados por dois tipos de "encenações": um, o espetáculo e, o outro, o carnaval. O argumento utiliza-se daquilo que Burke (1969) chamou de "retórica de motivos". A retórica para Burke é "o uso da linguagem como um meio simbólico de induzir cooperação em seres que por natureza respondem a símbolos" (Burke, 1969). Nossa condição humana responde à discussão do mercado. O espetáculo usa do motivo do grupo para unir-se e compartilhar os ícones e símbolos, para que as mesmas atitudes em relação à moda, à linguagem, ao consumo e à produção possam se desenvolver. À margem disso, existe a resistência.

\section{CONTROLE DO ESPETÁCULO SOBRE 0 CARNAVAL}

Enquanto redes de movimentos sociais e grupos de protesto juntam-se em protestos anuais, como o "dia de boicote à Nike" ou as recentes ações contra a WTO, o WB e o FMI, as empresas, as indústrias e a polícia constróem "salas de guerra" que monitoram e ficham estudantes e outros indivíduos e grupos de protesto. Por exemplo, a sala de guerra da Nike alista administradores em universidades com contratos lucrativos de licença da empresa para que eles relatem com antecedência quaisquer ações planejadas em uma NikeTown ou um discurso ou, ainda, show de moda anti-sweat a ser feito no campus. O poder é também mais direto. Quando o chefe executivo da Nike Inc., Phil Knight, soube que a University of Oregon tinha se unido à anti-sweatshop Workers Rights Consortium (WRC) parou de comparecer aos eventos esportivos da universidade e desistiu de fazer uma doação de US\$ 30 milhões (Wall Street Journal, 10 abr. 2001).

Recentemente, a University of Oregon anunciou que não mais iria trabalhar com a WRC ou a FLA. Em Beaverton, Oregon, a sala de guerra da Nike tornou-se uma operação constante de "times virtuais" de executi- vos e consultores terceirizados para responder aos protestos como os que ocorrem nas Truth Tours ${ }^{5}$ anuais nas lojas NikeTown, às ações em encontros de acionistas que primeiramente foram tirados do Oregon e, recentemente, movidos para fora do país para controlar o acesso de manifestantes -, aos sit-ins em universidades e aos dias mundiais de boicote à Nike. Por exemplo, Vada Manager, diretor de assuntos globais da Nike, "recebeu notícias adiantadas de uma Truth Tour por meio de uma rede de representantes pagos, estudantes e administradores amigáveis em mais de 200 universidades que tinham contratos de produtos da Nike... o time da Nike pegou vídeo-tapes das brigas em Nova York e os repassou, junto aos perfis dos ativistas da RV (baixados do website da Truth Tour), para policiais ao redor da rota". "Não é de nossa cultura retrair, ou nos mantermos de boca fechada", diz Amanda Tucker, membro da sala de guerra (Emerson, 2001). Tais salas são geralmente campanhas de relações públicas para prevenir táticas carnavalescas de obtenção de atenção da mídia por parte dos que protestam. Por exemplo, companhias no estado de Washington fazem com que suas salas de guerra respondam mais rapidamente às acusações que certamente seriam feitas nos protestos da WTO em Seattle. Salas de guerra são formas de líderes em negócios lutarem contra as críticas radicais. Coligações de ativistas fazem em suas próprias salas de guerras contra-argumentos e comunicados à imprensa pró-comércio. O monitoramento corporativo de desordens civis e o monitoramento ativista de violações de códigos de conduta corporativos constróem o campo de atividade de jogos de guerra pósmodernos, uma nova política de conflito entre espetáculo e carnaval, em que:

- As encenações são armas para atrair a atenção da mídia;

- O conhecimento é obtido por meio de espionagem e monitoramento;

- As informações são acumuladas e disseminadas com rapidez por muitos fronts;

- As salas de guerra competem para bloquear as estratégias de mídia uma das outras;

- Os dois lados competem por uma vantagem ética alta;

- A alta tecnologia - inclusive inteligência artificial - é a chave para sustentar a vantagem competitiva.

Os resultados dos protestos, entretanto, têm sido insignificantes. Apesar de ter havido um aumento desses protestos, a resposta a um maior monitoramento das condições não mudou drasticamente as condições de trabalho. Em vez disso, tem havido um enorme crescimento na indústria de auditoria e monitoramento, na qual 
consultorias como a PricewaterhouseCoopers (PwC) e a Ernst and Young (E\&Y) monitoram as condições das fábricas contra códigos de conduta corporativos e industriais. Essa tendência é perigosa, já que privatiza padrões de imposição de direitos humanos e de trabalho, enquanto deixa governos e administradores públicos saírem ilesos.

O monitoramento é um discurso excessivamente racionalista, objetivista e cientificista enraizado na ideologia instrumental do capitalismo de livre mercado, que inclui a intervenção mínima do governo na conduta das empresas. Para os céticos, o monitoramento, nos exemplos aqui apresentados, é estrategicamente feito como um pedido de desculpas, tirando dos trabalhadores suas vozes de protesto. Aqui se fazem necessárias algumas observações que apóiam a proposta de que o monitoramento não é um ato discursivo emancipatório ideal.

\section{(A) Critérios de discursos autênticos não preenchidos}

Monitoramento é um dispositivo retórico que não preenche os critérios de discursos autênticos, como teorizado por Habermas (in Fox e Miller, 1995).

Por exemplo, Roberts e Bernstein (2000) investigaram uma fábrica chinesa, a Chun Si, subcontratada para produzir bolsas Kathie Lee Gifford para Wal-Mart e Payless ShoeSource, em que "seguranças batiam com frequência em trabalhadores que respondiam aos gerentes". Relatórios de auditoria da PwC e Cal Safety Compliance Corporation em cinco inspeções anteriores haviam deixado de perceber sérios problemas. Em novembro de 2000, a Chun Si tentou enganar monitores enviados para inspecionar a fábrica e verificar suspeitas de horas-extras excessivas. Para passar pela auditoria dos monitores, a gerência fez uma "plástica" em um dos andares - adicionando papel higiênico e pintando banheiros encharcados - e melhorou as condições de 200 trabalhadores - aumentando salários, diminuindo as horas excessivas e instalando uma linha de telefone direta com o número 1-800-WM-ETHIC do Wal-Mart. Ao mesmo tempo, os outros 700 trabalhadores foram removidos para o $4^{\circ}$ andar - onde as condições de trabalho pioravam com jornadas de trabalho de 14 horas e altas taxas cobradas por refeições -, e forçados a assinar contratos afirmando que não mais trabalhavam para a Chun Si. Ambos os andares ainda produziam bolsas Kathie Lee.

O'Rourke (2000) acompanhou auditores da PwC certificados pela WRAP - em inspeções de fábricas na China e na Coréia e avaliou auditorias de uma fábrica na Indonésia. Ele concluiu que os métodos de monitoramento da $\mathrm{PwC}$ contavam com informações dadas principalmente por gerentes, as entrevistas eram conduzidas na presença de gerentes, era permitido que gerentes escolhessem os trabalhadores a serem entrevistados e os monitores avisavam como obter as notas necessárias para passarem na inspeção. Os relatórios de monitoramento deixavam de observar violações de saúde e segurança isto é, uso de produtos químicos perigosos, falta de luvas e óculos para proteção -, barreiras para a liberdade de associação, violações às leis de salário e horas-extras, e bancos de horas falsificados. "O programa inclui esforços de preparar gerentes para o processo, dar garantias de confidencialidade a eles e até enviar previamente questionários para que se preparem com antecedência para os critérios com os quais serão avaliados" (O'Rourke, 2000). Quatro observações seguem essas e outros estudos similares de monitoramento.

Primeiramente, a participação no diálogo não é igual; trabalhadores, donos de empresas sub-contratadas e executivos corporativos globais não falam realmente entre si. Existe uma estrutura e uma hierarquia social dominante na qual monitores falam pelos trabalhadores, escolhidos pela gerência, escrevendo relatórios gerados por valores de relações públicas. Segundo Fox e Miller (1995), "a comunicação requer participantes em igualdade". Os trabalhadores não têm oportunidades iguais de participação nos diálogos; eles falam nos espaços vigiados pelos monitores. Além disso, "o discurso autêntico requer confiança entre os participantes" (Fox e Miller, 1995). Em segundo lugar, o monitoramento não é uma arena comunicativa ideal. As pessoas que defendem a indústria de roupas atléticas e de universidades são consultores pagos e certificados por outras consultorias como WRAP, GA e FLA - todas essas afirmam ter fins não-lucrativos. Acadêmicos, como Kahle, Boush e Phelps (2000) têm acesso especial a "fábricasmodelo" e publicam versões do staff das empresas sobre os comunicados à imprensa que acabam sendo republicados em periódicos acadêmicos. Em terceiro lugar, no ato do discurso de monitoramento, a hierarquia de espionagem acaba com a autenticidade; os trabalhadores têm pouca ou quase nenhuma autoridade para se expressarem. E, em quarto lugar, o discurso autêntico dá-se cara-a-cara em um ambiente de confiança, não de coerção.

\section{(B) Alegações de validade não são confiáveis devido ao discurso coagido e às palavras compradas.}

O monitoramento dá fachadas discursivas às vozes dos trabalhadores e participação em afirmações de autenticidade e validade. Fox e Miller (1995) aplicaram quatro afirmações de validade de Habermas à Administração Públi- 
ca: (1) entendimento, (2) a verdade do conteúdo preposicional, (3) sinceridade do orador, e (4) qualidade da performance do discurso.

Em primeiro lugar, o relatório de monitoramento é compreensível de uma maneira corporativa, mas também é uma história que pode ser contada de maneira diferente por trabalhadores livres de coerção e da vigia gerencial. Por exemplo, Boje (2001d) comparou o estudo da UCM (1999) com outro feito nas mesmas fábricas da Nike na Indonésia pela GA (CSDS, 2000), notando diferenças em seus métodos, resultados e conclusões. Enquanto ambos entrevistaram 4 mil trabalhadores e encontraram momentos de abuso verbal, o estudar da UCM contrastou as fábricas da Nike com outras fábricas, mostrando que as condições são muito piores fora da Nike. Os monitores não são oradores autônomos, tampouco independentes. No estudo da CSDS (2000), contratado pela GA, trabalhadores não foram perguntados sobre horas extras forçadas nem tiveram oportunidade de expressar suas preocupações. Os gerentes da fábrica e membros do staff da Nike controlaram o processo. Empresas de consultoria contratadas ( $\mathrm{PwC}$ ), credenciadas por grupos industriais (WRAP) e associações (FLA) financiadas pelas empresas contratantes (Nike, GAP, etc.) são parte de um discurso vazio. Em segundo lugar, nos exemplos de relatórios de consultoria da GA - por exemplo, CSDS, 2000 -, as alegações de autenticidade omitem certos conteúdos preposicionais - preocupações dos trabalhadores sobre horas extras forçadas, salários inadequados e falta de liberdade para falar, tampouco associar. Em terceiro lugar, a sinceridade do monitor enquanto porta-voz dos trabalhadores é suspeita nesses casos (O'Rourke, 2000; Roberts e Bernstein, 2000; Boje, 2001c; Stabile, 2000). Em quarto lugar, a qualidade da performance do discurso pode significar que a identidade dos trabalhadores é mantida confidencial, mesmo que suas entrevistas e grupos de discussão sejam, em alguns casos, conduzidos na frente dos gerentes da fábrica, os quais os próprios trabalhadores estão monitorando a pedido dos monitores (Boje, 2001d). Na amostra da CSDS (2000), a identidade da fábrica é mantida confidencial apesar de alegações de assédio sexual e abuso físico feitas pelos trabalhadores naquele relatório. Em resumo, alegações de validade dos monitores são problemáticas. Monitores são "vozes contratadas", incapazes de um discurso independente deliberado, que uma vez já foram a província da administração e legislação pública. Baseados nos casos analisados, eles fazem falsas alegações sobre o discurso das regras.
(C) 0 monitoramento solicita o discurso, mas não promove um diálogo democrático.

Empresas e fábricas subcontratadas prometem mudanças, mas a intenção do monitoramento é a legitimidade, não a reforma. Se a intenção do monitoramento é a liberdade total de expressão, as formas atuais de participação dos trabalhadores são nada mais do que um discurso dominado pelas empresas. É difícil promover diálogo quando o discurso é coagido - isto é, quando trabalhadores são despedidos por terem protestado contra suas condições de trabalho. Trabalhadores - na fábrica de Kukdong, por exemplo - são multados por falar enquanto trabalham (Boje et al., 2001). Na China, proibições de conversa podem se estender a conversas de trabalhadores no horário do almoço (Chan, 1996). Em Kukdong, a conversa com outros trabalhadores é motivo para demissão.

A Sra. Lap Nguyen foi demitida de uma fábrica da Nike - Sam Yang, uma fábrica coreana de tênis contratada em Ku Chi, Vietnã. Lap Nguyen foi rebaixada diversas vezes depois de ter uma entrevista, autorizada pela gerência, televisionada em 2 de Abril de 1998 pelo programa "Outside the Lines" (ESPN, 1998). Nguyen alega que foi forçada a se demitir. Gerentes coreanos, temerosos que essa publicidade resultaria no fim de seu contrato com a Nike, rebaixaram Nguyen primeiramente para uma linha de produção com trabalhadores mais jovens e em menor número, mas com um nível de produção muito mais alto. Quando ficou doente tentando se manter no ritmo mais forte dos colegas, ela diz que lhe foi negada a licença médica, foi rebaixada a limpadora de banheiros e depois eventualmente forçada a demitir-se. Recentemente foi diagnosticada com tuberculose e, apesar de grandes protestos dos ativistas para que a Nike a recontrate, ela continua desempregada.

O discurso dos monitores solicita respostas dos trabalhadores e gerentes, mas não promove o discurso livre e democrático, nem leva a mudanças que significariam uma liberdade de associação.

\section{(D) Elites controlam a agenda, enquanto que a} participação dos trabalhadores legitima o status quo.

O monitoramento é um método retórico que não preenche os critérios do discurso autêntico, mas que influencia as opiniões pública, legislativa e administrativa. No estudo de Andrew Young e Jordan Hamilton (1997), as empresas fornecem os tradutores, os gerentes de fábrica selecionam os trabalhadores a serem entrevistados e selecionam as fábricas a serem visitadas. Relatórios nãoindependentes podem omitir, maquiar, ignorar e emba- 
çar questões que outros estudos podem entender como importantes para os trabalhadores (UCM, 1999). Os estudos da PwC, por exemplo, sugerem que as respostas dos trabalhadores e gerentes às perguntas dos monitores são ensaiadas e que estes ensinam os trabalhadores a responder quando as perguntas e horários de consulta das visitas monitoradas são entregues com antecedência (O'Rourke, 2000; Roberts e Bernstein, 2000). No caso da sub-contratada pelo Wal-Mart, isso dá à gerência da fábrica tempo e licença para ensaiar performances teatrais que satisfazem os requerimentos dos monitores. Em resumo, o monitor no local de trabalho negocia a rendição das violações dos direitos humanos e as questões de cumprimento de regras a serem publicamente mostradas, para que tudo seja verossímil como espetáculo.

\section{(E) 0 monitoramento é uma apropriação da} participação do trabalhador no discurso democrático.

"Sob condições pós-modernas", Fox e Miller (1995) afirmam que "a exclusão do discurso ocorre de maneiras não-democráticas". Relatos de abuso físico e sexual, violações de salários e horas-extras, e violações de políticas ambientais e leis nacionais são sistematicamente coletados e tabulados, mas não para o propósito de participação democrática (CSDS, 2000). Monitoramento não é um ato discursivo liberatório; esse é um trabalho para relações públicas. O monitoramento tira o poder dos trabalhadores; o monitor fala por eles, eles não falam por si mesmos.

Uma maneira de transmitir a participação no monitoramento é, ironicamente, assegurando o anonimato dos trabalhadores ao darem suas respostas. Relatórios da Verité (2001) e CSDS (2000) para GA, FLA e Nike não indicam os nomes dos trabalhadores nos relatórios. Eles não gravam entrevistas ou tomam notas e os materiais de pesquisa são entregues à empresa após tais estudos. Por um lado, o apelo da confidencialidade para proteger os trabalhadores de retaliação dos gerentes parece sensato, mas tem seu lado negativo. Trabalhadores não conseguem estabelecer suas vozes e suas histórias viram breves frases e percentuais. Esse anonimato é visto como uma virtude nos projetos de monitoria, uma vez que, no caso de trabalhadores falando com a imprensa, houve retaliação - por exemplo, a Sra. Lap Nguyen. Alternadamente, relatórios de ativistas e jornais listam trabalhadores pelo nome - quando a permissão é obtida -, logo dando-lhes identidade e incluindo relatos mais extensos de sua situação (Boje et al., 2001). O outro lado da questão de identidade envolve as maneiras com que os relatórios de monitoramento man- têm anônima a identidade de entrevistadores e relatores. Fox e Miller (1995) antecipam minhas preocupações com o monitoramento: "O anonimato do orador é preservado quando agentes de propaganda, atores pagos ou empresas contratadas constroem e entregam suas mensagens persuasivas. Têm direito ao mesmo anonimato: escritores de questionários, respondentes de questionários e tecnocratas anônimos que codificam a informação."

$\mathrm{O}$ anonimato pode se apropriar e manipular a voz do trabalhador. Além disso, a identidade das fábricas mantida em segredo nas comparações feitas pela CSDS (2000) para a GA e a Nike torna as acusações de abuso e violação legal impossibilitadas de serem julgadas publicamente.

Em resumo, concluo que o monitoramento apenas em aparência inclui a voz do trabalhador, mas é uma participação controlada ao máximo e, na pior das hipóteses, coagida.

Minha visão mais radical sobre monitoramento é que ele facilita a escravidão dos trabalhadores em sweatshops ao subjugar seus discursos e liberdade de associação em maneiras que resistem mal ao poder corporativo, enquanto mantém o regulamento e a barganha coletiva encurralados. Especialistas da indústria de consultoria e monitoramento fazem do local de trabalho um prelúdio aos relatórios corporativos para a imprensa e para a platéia pretendida do monitoramento: consumidores, investidores, legisladores e administradores.

\section{CARNAVAL E ESPETÁCULO}

O carnaval é uma resistência à parte, um espelho da Society of the spectacle de Debord (1967). O espetáculo foi uma vez uma maneira do poder do Estado e da Igreja manterem as massas sob controle. Enforcamentos e torturas públicas na praça principal eram eventos amplamente vistos, nos quais os acusados poderiam ser redimidos aos olhos de Deus se o carrasco falhasse em sua tarefa. Foucault (1979) ilustra esse ponto nas cenas iniciais de Discipline and punish, mostrando a tortura de Damien em detalhes violentos; a amputação de suas mãos e membros depois do esquartejamento não mostravam os talentos do carrasco, nem o controle do Rei. Enquanto esses espetáculos perdiam o controle, o carrasco tinha de usar mais cortes de faca e a mensagem tornava-se mais uma acusação da falta de poder da coroa e uma expressão da provável inocência de Damien. Foucalt argumenta que o espetáculo de tortura deixou de ser exibição pública e se tornou privado para que a modernidade pu- 
desse dar-lhe o adequado controle burocrático. O argumento aqui é que o espetáculo ressurgiu com novas tecnologias, a fim de controlá-lo como consumo público, em face das formas carnavalescas de desafio e resistência.

O carnaval da Idade Média faz-nos lembrar imagens de palhaçadas e sátiras medievais ultrajantes, a paródia da religião e da coroa, nádegas e seios nus, máscaras e fantasias. Porém, isso também era aparente em Woodstock, nas manifestações em Paris em 1968, na Guerra do Vietnã e em protestos de direitos civis da época. Desde os protestos na World Trade Organization (WTO) em Seattle, temos testemunhado um aumento das batalhas coreografadas entre polícia e ativistas carnavalescos engajados no teatro de rua completo com fantasias, máscaras e bonecos.

Bakhtin (1981) enxergou nas encenações teatrais a ridicularização do poder pelos camponeses, a inversão da hierarquia, as violações do decoro e da proporção e a celebração do excesso corpóreo, incluindo a mutilação. Vê-se um ressurgimento do carnaval (mas não o tipo encontrado em circos) e também das encenações usadas para protestar contra a globalização. Como Kristeva (1980b) colocou, o autor é "autor + espectador" e parte da cena carnavalesca, dos atos de produção, distribuição e consumo. Nós também somos parte da cena carnavalesca, como espectadores, autores e atores. Kristeva (1980b) argumenta que cada texto tem uma trajetória intertextual de "coordenadas históricas e sociais". Pode ser possível rascunhar as coordenadas do ressurgimento do carnaval em sua oposição ao espetáculo para que estudos futuros possam projetar totalmente sua trajetória.

É importante observar que Bakhtin (1981) não teorizou o carnaval como "irracional", mas como sistema de símbolos que competem por autoridade representativa, para vender uma maneira de interpretar posições polifônicas outrora subjetivas, incluindo a legitimação de práticas trabalhistas e luta por idéias. É fácil tratar pessoas vestidas em cascos de tartarugas ou desfilando nuas para protestar contra a fabricação de roupas como irracionais. Bakhtin usou o termo "carnaval" para identificar uma atmosfera de festança, desprezo a autoridade e antiintelectualismo somático na literatura. Observa-se isso no protesto contemporâneo.

Kristeva (1980b) observa que "a cena do carnaval apresenta o ato de discurso dividido: o ator e a platéia são simultaneamente assunto e destinatário do discurso". Em resumo, carnaval é uma resposta estratégica a sentimentos atuais de alienação ao poder corporativo, mas também é parte daquele poder - trabalhamos para ele e compramos dele. Existe também uma negociação com o poder sobre os termos de compromisso. Isso é aparente na maneira com que os demonstradores na WTO negociam com a polícia concordando, por exemplo, em ser mais pacificamente presos se a polícia usar meios menos violentos de controle da multidão. Áreas especiais são reservadas para protestos e ativistas participam de campos de treinamento para aprender como agir em uma maneira civilmente desobediente, enquanto a polícia e o exército em seus próprios campos aprendem a intimidar infligindo dor, mas sem causar danos ao corpo.

Nos shows carnavalescos de moda sweatshop de hoje, modelos pacíficas e locutores subvertem o tradicional show de moda com histórias de mulheres que fazem roupas de marca e sapatos esportivos. A moda é associada ao glamour e às marcas de designers que são justapostas a condições abusivas e exploradoras de trabalho, problematizando portanto a decisão da próxima compra do consumidor. Shows de moda anti-sweatshop são também roteirizados para conscientizar estudantes, professores e funcionários, e encorajar espectadores a juntarem-se à campanha para códigos mais rígidos de conduta para o vestuário licenciado pelas universidades. Estudantes e professores pesquisam empresas e marcas à venda em lojas no campus, buscam histórias de trabalhadores e preparam o roteiro do próximo show de moda. Personagens e locutores ensaiam suas falas, a trilha sonora é selecionada - por exemplo, "You sexy thing" de Hot Chocolate, "Barbie girl" de Aqua e "Are my hands clean?" de Sweet Honey in the Rock. Existe muito trabalho antes do evento: além da escolha de músicas e falas, a passarela é desenhada, vestuários são emprestados (não comprados) e a mídia é convidada a cobrir o evento. Um final pode incluir atores voltando ao palco para reiterar mensagens-chave sobre empresas e pedir à platéia que ajude a lançar uma campanha de código de conduta. É pedido que os espectadores conscientizem-se de onde as vestimentas são feitas e sob quais condições, exijam que as empresas liberem publicamente nomes e localidades de fábricas em sua cadeia de suprimento e permitam monitoramento independente das condições de trabalho. Existem abaixo-assinados, petições, cartasmodelo ou cartões e materiais de fundo.

Porém, levar os shows de moda sweatshop às ruas é menos seguro do que encenar performances nas universidades. A sequência do teatro de rua ao carnaval de resistência à WTO nas ruas de Seattle são os protestos contra o WB, o FMI e o recente encontro em Quebec da Área de Livre Comércio das Américas (ALCA). Enquanto helicópteros circulavam por cima de cruzamentos congestionados por manifestantes, a polícia usava armadu- 
ras por todo o corpo e capacetes negros, parecendo esquadrões de protesto do Darth Vader, demonstrando uma moda milionária similar aos uniformes dos storm troopers de "Guerra nas estrelas", veículos blindados como os do exército e armas compradas especialmente para tais protestos. "Quando uma van cheia de delegados foi cercada e imobilizada na esquina da 15 th street com a Pennsylvania, a polícia montada partiu para cima da multidão, batendo nos manifestantes com cacetetes, atropelando alguns com seus cavalos. Os ativistas tentaram manter suas posições, gritando: 'Todo o mundo está assistindo' e 'Nós não somos violentos!'... Com a multidão como cobertura, anarquistas com armas de tinta spray deixaram sua marca na parede da loja GAP na 20th Street: 'MODA SWEATSHOP'”. (Weinberg, 2000).

Uma rede solta de movimentos sociais e grupos de protesto que variam de direitos dos animais até sindicalistas está se organizando em solidariedade aos trabalhadores do Terceiro Mundo, usando performances carnavalescas para dar um fim ao aumento das sweatshops que tais ativistas alegam ter sido causado pela globalização. "A polícia de Washington D.C. tinha aprendido as lições de Seattle e conseguido evitar que cenas espetaculares de lutas de rua chegassem às telas de TV do país, enquanto usava métodos contra os manifestantes mais insidiosos e não menos brutais do que os empregados em Seattle... Ao meio-dia da sexta-feira, um caminhão alugado pela People for the Ethical Treatment of Animals descarregou quatro toneladas de estrume na Pennsylvania Avenue perto do QG do World Bank" (Weinberg, 2000).

\section{Outras formas de carnaval}

A UNITE e a Coalition for Maquiladora Workers' Dignity (COSDEMA) fizeram uma campanha estrelando a Guess, em uma inteligente paródia de um catálogo de pedidos pelo correio usando uma empresa fictícia chamada Sweat International que vende uma linha de roupas sweat feitas em antigas sweatshops em El Salvador (SweatGear, 2001). Na Califórnia, diversas universidades organizaram "aulas de costura" e shows de moda e exigiram que administradores aprovassem códigos de conduta revisados, que se unissem à WRC - patrocinada pela USAS - e deixassem a FLA - patrocinada por empresas. Em resumo, shows de moda e de costura aumentam a conscientização das condições de trabalho nas quais as vestimentas são produzidas. A seguir serão analisadas as novas tendências nas ações de carnaval e espetáculo, o uso da desobediência cibercivil e contraestratégias de espetáculo.

\section{DESOBEDIÊNCIA CIBERCIVIL}

O espetáculo e o carnaval levaram sua luta pela fidelidade do público para a Web. A Internet está alterando o cenário do discurso político, do protesto e da resistência. Desde a última década, o número de visitantes a sites de empresas e governos compete com o número de visitantes a sites de direitos humanos, ecológicos, animais e civis. A Internet problematiza a idéia de fronteiras internacionais e controles corporativo e estatal de discurso no ciberespaço. Tradicionalmente, o uso mais radical de computadores tem se restringido ao envio de e-mails e publicação de artigos em listas e sites. Recentemente, no entanto, táticas mais radicais de discurso na Web escalaram invasão, interrupção e bloqueio de sites de empresas. Existe uma grande guerra cibernética de oposição não-violenta travada diariamente no território da Internet enquanto críticos trabalhistas, indígenas, anti-sweatshops, pessoas contrárias a alimentos alterados geneticamente, ativistas de direitos animais e outros críticos do livre comércio e da WTO estão se direcionando a formas mais diretas de ação, postando artigos em listas de discussão ou soltando a língua em uma página na Web - as táticas de campanhas de rua e o carnaval estão sendo imitados no ciberespaço.

Empresas estão protegendo sua máquina de conhecimento de espetáculo contratando magos da computação para defender seus sites de ataques, contratando firmas de relações públicas para criar campanhas de contra-informação e mais consultores para produzir relatórios científicos que afirmam que os produtos da empresa são seguros, produzidos por trabalho "livre" e beneficiam os consumidores assim como o meio-ambiente. Os grandes produtores na indústria de roupas atléticas e de universidades, por exemplo, têm sites elogiando suas práticas trabalhistas e ambientais. A indústria bio-tecnológica tem um site que legitima suas práticas com relatórios científicos - http://www.whybiotech.com. Atores de espetáculos - incluindo FMI, WTO, oficiais do WB e empresas - estão afirmando que houve uma grande mudança nas economias das nações asiáticas outrora em crise. O espetáculo do capitalismo tardio moderno é a reengenharia social da rede de sites que podem consolar e persuadir consumidores e investidores. Novas formas de ciberativismo são uma reação natural ao espetáculo da mídia em massa e à restrição a protestos de rua, enquanto interesses corporativos presentes celebram o progresso global. Navegar pela "ciência do lixo" e pela desinformação colocadas à mostra por empresas multinacionais como a Monsanto, que alega que 
seus produtos diminuem a fome no mundo, ou inúmeros anúncios greenwash dizendo que as empresas são ecosustentáveis, é uma tarefa difícil, mas possível de ser pesquisada.

O espetáculo corporativo usa imagens descontextualizadas e gráficos flutuantes de ícones do esporte e celebridades para mostrar seus produtos como heróicos e de última moda. Só às vezes vemos transparência no espetáculo, como nas imagens de policiais Darth Vader confrontando pessoas unidas em atos de liberdade de expressão, mas isso é rapidamente transformado em caricaturas e infinitas reprises de algumas cenas de algazarra, caos e vidros quebrados da NikeTown e Starbucks, enquanto filmes de protestos não-violentos não são vistos como dignos de serem noticiados. Protestos nãoviolentos na WTO, no FMI e no WB não dão audiência nem lucros.

Não apenas o espetáculo, mas o carnaval está sendo digitalizado e virtualizado, transferindo as táticas de movimento social de invasão e bloqueio para a Internet. Diversos movimentos sociais e grupos de protesto levaram o show antiglobalização para o ciberespaço. Na conferência da WTO em Seattle em 1999, os "electro-hippies" organizaram sua primeira grande ação virtual - um "sitin virtual" na conferência da WTO e nos servidores da empresa. Um sit-in tradicional acontece quando as pessoas posicionam-se na frente de alguma entrada, ou dentro de um prédio, e permanecem sentados lá como uma forma de protesto pacífico. Sit-ins virtuais encontram maneiras de ocupar lugares no ciberespaço, como sites de sistemas de informação pública na Internet. Bots (programas de robôs digitais), por exemplo, podem automaticamente recarregar uma web page escolhida a cada segundo ou mandar grandes arquivos de imagens para ocupar a largura da banda do servidor, impedindo outras informações de moverem-se para dentro ou fora do site, interrompendo o tráfego ou acumulando exigências de capacidades até que o servidor caia.

O "hacktivismo" combina hacking com ativismo, mirando sites corporativos, da WTO, do WB, do FMI e outros para atrapalhá-los - sit-ins na Web, bloqueios virtuais, redirecionamentos, e-mails-bomba automatizados -, mas a intenção não é causar sérios danos às pessoas ou propriedades (Denning, 1999). Hacktivismo é desobediência eletrônica civil não-violenta que permite sit-ins virtuais em um nível global (Kaplan, 1998). O ciberterrorismo, por outro lado, age anonimamente para causar destruição de propriedade e humana. O hacktivismo pode resultar em perda de dólares em vendas, como quando a Nike.com foi redirecionada para
S11.org por 19 horas, das 15 ou 16 horas, horário de Melbourne, na quarta-feira 21 de julho de 2000, até por volta de 11 horas de quinta-feira 22 de julho de 2000.

O Electronic Disturbance Theater iniciou seu primeiro ato de desobediência civil eletrônica em abril de 1998 tentando parar a guerra no México, apoiando os Zapatistas em Chiapas (ver http://www.nyu.edu/projects/ wray/ecd.html para mais detalhes). O grupo do Reino Unido, Electrohippies, alistou 452 mil internautas para que bombardeassem o web site da WTO durante seu sitin virtual. Atualmente, existe um protesto on-line contra a conferência da Área de Livre Comércio das Américas em Quebec e uma ferramenta de demonstração zapatista distribuída no web site da Electronic Disturbance Theater (Electrohippies, 2001).

Em 26 de setembro de 2000, ciberativistas franceses auto-intitulados Federation of Random Action (FRA) fizeram um sit-in virtual de "liberdade de expressão" que durou 12 horas, encorajando internautas no mundo inteiro a baixar e usar um brinquedo de chat-room que inundava os servidores do FMI e do WB com pedidos para informação e reclamações sobre desigualdades econômicas na economia global. Enquanto os "e-manifestantes" digitavam, o programa marcava palavras-chave como pobreza, finanças, investimento e poder financeiro. Cada vez que essas palavras apareciam, o programa mandava pedidos por informação aos sites do FMI e do World Bank. Também mandava mensagens de erro como "Nossa vida não está à venda", "Por favor, destrua-nos também!" e "Vocês vendem barbeadores de ovelhas?" (Ferguson, 2000).

Este é o "e-carnaval", uma forma cibernética de paródia, imitando o teatro de rua e digitalizando a resistência teatral ao capitalismo global. Esses grupos de e-carnaval utilizam a Internet como um meio viável de discordância, desobediência e protesto público espelhando meios tradicionais de expressão política e social que existem na sociedade cotidiana.

Relevante à Administração Pública é a alegação de que o ciberprotesto é uma nova forma de discurso civil desobediente e uma alternativa crítica pós-moderna para a participação democrática tradicional. Interesses corporativos procuram incriminar o protesto na Internet, não apenas o hacktivismo, mas os protestos bloqueadores não-violentos que revertem e recontextualizam os significados de logotipos e slogans, e a invasão a web sites de empresas e grupos de comércio com discursos radicais por grandes ralis virtuais e sit-ins que os sobrecarregam. 


\section{CONCLUSÕES}

O monitoramento encaixa-se na definição do lado negro da participação (Fox e Miller, 1995), no qual "poucos falam", enquanto confinados em dispositivos de monólogo. É uma situação de discurso dominado pela elite e por especialistas, na qual poucos falam somente quando são - e o que são - ordenados a falar. Ativistas, por outro lado, estão em um contexto no qual "muitos falam", mas o discurso é desorganizado e não domina o discurso público. O papel que a Administração Pública pode ter é de preencher o espaço entre os que "pouco falam" e os que "muito falam". Isso significa manter as vias cibernéticas e ruas públicas abertas ao protesto civil desobediente, protegendo corporações de ações mais violentas.

Será que os cibercafés e os sit-ins virtuais estão em um espaço onde pode ocorrer um sério debate político? Isso é um carnaval, uma maneira de parodiar e chamar atenção às injustiças. O carnaval é uma questão de liberdade de expressão. É também uma estratégia dos movimentos humanos, trabalhistas e de eco-direitos. Esses direitos são constituídos por múltiplos discursos que se sobrepõem, que constituem jogos de linguagem neo-tribais e por muitas vezes incomensuráveis entre os interesses corporativos e dos ativistas.

A Administração Pública pode retomar o terreno perdido para a disseminação do monitoramento dos direitos humanos colonizado pela indústria das consultorias. Depois do "poucos falam" na indústria de monitoramento, podemos esperar que o "muitos falam" dos participantes dos movimentos anti-sweatshop exemplifique o discurso democrático. Mesmo assim, parece que, quando muitos falam, especialmente por e-mail, em listas de discussão e em chat-rooms, nada acaba sendo feito. Pode ser um papel viável para a Administração Pública focar o carnaval em projetos de ação. Depois de muitos falarem no teatro de rua ou virtual, a Administração Pública pode levar a projetos de direitos humanos.

Pode o carnaval estimular debates? Os estudantes de $2^{\circ}$ e 3 graus estão se envolvendo em lutas por direitos humanos em números não vistos desde os protestos contra a guerra no Vietnã e pelos direitos civis. Ao mesmo tempo, administradores de universidades parecem divididos entre acordos de licença corporativa e preocupações estudantis (e de parte do corpo docente) sobre a origem de suas roupas. Existe mais debate nas universidades, mas também há mais interferência das empresas nos currículos.

Enquanto o mundo torna-se mais fragmentado, é me- nos provável que o discurso carnavalesco possa competir com o discurso bilionário em propagandas construído por empreendimentos corporativos transnacionais (Box, 1996). O carnaval pode não parecer racional para seus detratores, mas constitui uma estratégia de resistência.

McSwite (1997a) e King e Stivers (1998) pediram um papel mais viável da Administração Pública nas relações democráticas. Fox e Miller (1995) vêem a teoria da Administração Pública pós-moderna como algo que preenche esse requisito. Pode ser que a participação civil - de trabalhadores e membros da comunidade em atos de carnaval seja uma maneira de opor-se ao espetáculo corporativo da mídia, até que a Administração Pública escolha uma maneira de ter um papel mais significante na prática.

Rosa Luxemburgo uma vez disse que, se ela não podia dançar na revolução, ela não queria participar dela. $O$ carnaval é parte da carne e do sangue da vida, a alegria da dança, os desafios ousados aos espetáculos de poder e dominação. Um show de moda ou um grito rebelde ou, ainda, vestir máscaras em um protesto na WTO parecem ser pequenos desafios. Entretanto, enquanto muitos grupos unem-se, algumas vozes são escutadas acima das mesmas imagens de lojas sendo quebradas mostradas na mídia, repetidas sem parar, até que seja a única imagem que a maioria das pessoas irá se lembrar.

Texto traduzido por Fabio Augusto Carneiro Leal da Silva. Artigo convidado. Aprovado em 02/07/2002.

\section{Notas}

Texto publicado originalmente em Administrative Theory and Praxis: special issue on Radical Organization Theory. Vol. 23 n. 3 p. 431-458.

1. sweatshop - fábrica onde as condições de trabalho são péssimas, os funcionários são mal tratados, mal pagos e trabalham muitas vezes como se estivessem em um regime de escravidão.

2. Outro - Conceito psicanalítico inaugurado por Lacan e muito utilizado na Análise do Discurso. "aquele que habita o inconsciente do sujeito, referindo-se à função imaginária do 'eu' e ao discurso do inconsciente" [LACAN, J. O Eu na teoria de Freud e na técnica da psicanálise (O Seminário - Livro 2). Rio de Janeiro: Jorge Zahar Ed, 1985. p. 142].

3. greenwash - termo não dicionarizado, utilizado normalmente para designar "desinformação disseminada por uma organização para apresentar uma imagem pública de preocupação com o meio-ambiente".

4. sit-in - tática civil de desobediência não-violenta. Os manifestantes ocupam uma empresa ou local público e permanecem sentados até que sejam forçados a se retirar ou tenham suas reivindicações atendidas. (Encyclopedia Britannica em http://search.britannica.com/eb/ article?eu=69772 acessado em 15/09/2002.) 
5. truth tour - termo não dicionarizado, utilizado para designar caminhadas de protesto, cujo trajeto e horário são pré-estabelecidos pelos manifestantes, visando denunciar as infrações de uma empresa.

\section{Referências Bibliográficas}

ALPERT, A. Statement to Manchester District Court, New Hampshire, 17 maio 1999. Disponível em: <http://www.afsc.org/nero/aastmt.htm>.

BAKHTIN, M. The dialogic imagination: four essays . Austin : University of Texas Press, 1981.

BAKHTIN, M. Rabelais and his world. (1st ed.) Cambridge: MIT Press, 1973.

BAUMAN, Z. Postmodern ethics. Oxford : Blackwell Publishers, 1993.

BEST, S.; KELLNER, D. Postmodern theory: critical interrogations. Nova York / Londres : Guilford Press, 1991.

BEST, S.; KELLNER, D. The postmodern turn. Nova York / Londres : Guilford Press, 1997.

BEST, S.; KELLNER, D. Debord, cybersituations, and the interactive spectacle. Forthcoming in Substance, 2000.

BISSELL, T. Sweatshop agreement analysis. Trim Bissell is national coordinator of Campaign for Labor Rights (1998). Disponivel em: <http:/ /www.cleanclothes.org/codes/iniapparall.htm> e <http://www.itcilo.it/ english/actrav/telearn/global/ilo/guide/apparell.htm > (for the AIP agreement). Acesso em 12 abr. 2001.

BOGASON, P. Public Administration and postmodern conditions: some American pointers to research after the year 2000. Administrative Theory E Praxis 1999, v. 21, n. 4, p. 508-15, 2000.

BOGASON, P. Postmodernism and American Public Administration in the 1990s. Administration and Society, 2000.

BOGASON, P. Public Administration and the unspeakable: American postmodernism as an academic trail of the 1990s. Roskilde University, 1999 , 56 p. Disponível em: <http://www.sscnew.ruc.dk/download/5-99.pdf>.

BOJE, D. M. Spectacles and festivals of organization: managing Ahimsa production and consumption. (Book in preparation for Hampton Press [CA], 2001(a).

BOJE, D. M. Phenomenal complexity theory and change at Disney: response to Letiche. Journal of Organizational Change Management, 200l(b).

BOJE, D. M. Tamara Manifesto. Tamara, Journal of Critical Postmodern Organization Science, v. 1, n. 1, p. 15-24, 2001(c). Disponível em: <http:/ /www.zianet.com/boje/tamaras.

BOJE, D. M. Comparison of the Urban Community Mission (UCM) urvey Report December 1999 to the Global Alliance. Center for Societal Development Studies (CSDS) 2000 study 2001(e). Disponível em: <http:/ /cbae.nmsu.edu/ dboje/AA/Boje_compare_GA_and_UCM_studies.htm>.

BOJE, D. M.; ROSILE, G. A.; CARRILLO, J. D. M. A. The Kuk Dong story: when the fox guards the hen house (2001). Disponível em: <http:// cbae.nmsu.edu/ dboje/AA/kuk_dong_story.htm>.
BOX, Richard C. The Institutional Legacy of Community Governance. Administrative Theory \& Praxis vol 18, n.2, p. 84, 1996.

BURKE, K. A rhetoric of motives. Berkley : University of California Press, 1969.

CARR, A. Putative problematic agency in a postmodern world: is it implicit in the text - can it be explicit in organization analysis? Administrative Theory E Praxis v. 18, n. 1, p. 79, 1996.

CHAN, A. Boot camp at the shoe factory, where Taiwanese bosses drill Chinese workers to make sneakers for American joggers. Washington Post, Washington-DC, 3 nov. 1996. Outlook Section, p. C-01.

CLEAN CLOTHES CAMPAIGN. Firings and suspensions at Disney / Haiti contractor. 31 jul. 1998. Disponível em: <http://www.cleanclothes.org/ companies/disneyl5-7-98.htm>.

COOPER, T. L.; YODER, D. E. The meaning and significance of citizenship in a transnational world: implications for Public Administration. Administrative Theory \& Praxis, v. 21, n. 2, p. 125, 1999.

CORPORATE WATCH. Action alert on Disney / Haiti. 20 ago. 1998. Disponível em: <http://www.corpwatch.org/trac/corner/alert/191.html>.

CRAIG, S. C. (Ed.). Broken contract? Changing relationships between Americans and their government. Boulder : Westview, 1996.

CSDS. Worker's needs and aspirations in nine Nike contract factories in Indonesia: an interim report. Center for Societal Development Studies (CSDS) for Global Alliance for Workers and Communities (GA). Disponível em: <http://www.nikebiz.com/labor/nike_gla_report.pdf>. Acesso em 9 mar. 2000.

CURRIE, M. Postmodern narrative theory. Nova York : St. Martin's Press, 1998.

CZARNIAWSKA, B. Narrating the organization: dramas of institutional identity. Chicago : University of Chicago Press, 1997.

DALTON, R. J. (Ed.). Citizens, protest, and democracy. Newbury Park : Sage, 1993.

DEBORD, G. Society of the spectacle. (Société du spectacle foi originalmente publicado em 1967 pelas Edições Buchet-Chastel, Paris; foi reimpresso em 1971 pela Champ Libre, Paris). Íntegra do texto em inglês disponível em: <http://www.nothingness.org/SI/debord/index.html>.

DENNARD, L. F. The three bears and Goldilocks meet Burrell and Morgan. Administration and Society. v. 21, n. 3, p. 384-6, 1989.

DENNARD, L. F. The democratic potential in the transition of postmodernism: from critique to social evolution. American Behavioral Scientist, v. 41, n. 1, p. 148-62, 1997.

DENNARD, L. F. The Three Bears and Goldilocks meet Burrell and Morgan. Administration and Society. V. 21 n. 3 p. 384-386, 1989.

DENNING, D. E. Activism, hacktivism, and cyberterrorism: the Internet as a tool for influencing foreign policy (1999). Disponível em: <http:// www.nautilus.org/info-policy/workshop/papers/denning.html>. 
ELECTROHIPPIES. Web site (2001). Disponível em: <http:// www.gn.apc.org/pmhp/ehippies/high-index.html>.

EMERSON, T. Swoosh wars. Newsweek International. 12 mar. 2001. Disponível em: <http://stacks.msnbc.com/news/538847.asp>.

ESPN. Time line for Lap Nguyen, ESPN, and Nike (1998). Disponível em: $<1$ "ESPN_2000" http://cbae.nmsu.edu/ dboje/nike/ vietnam.html\#ESPN_2000>.

FARMER, D. J. The language of Public Administration: bureaucracy, modernity, and postmodernity. Tuscaloosa : University of Alabama Press, 1995.

FARMER, D. J. The language of postmodern administration: bureaucracy, modernity, and postmodernity. Tuscaloosa : University of Alabama Press, 1995.

FARMER, D. J. Derrida, deconstruction and Public Administration. American Behavioral Scientist, v. 41, n. 1, p. 12-27, 1997.

FARMER, D. J. The postmodern turn and the socratic gadfly. Administrative Theory \& Praxis, v. 18, n. 1, p. 128, 1996

FERGUSON, S. Hacktivists chat up the World Bank 'pecked to death by a duck'. Village Voice. 18-24 out. 2000. Disponível em: <http:// www.villagevoice.com/issues/0042/ferguson.shtml>.

FIRAT, F, A.; Dholakia, N. Consuming people: from political economy to theaters of consumption. Londres / Nova York : Routledge, 1998.

FOX, C. J.; MILlER, H. T. Postmodern Public Administration: a short treatise on self-referential epihenomena. Administrative Theory \& Praxis, v. 15 , n. 2, p. 52-70, 1995(a).

FOX, C. J.; MILlER, H. T. Postmodern Public Administration: toward discourse. Thousand Oaks : Sage, 1995(b).

FOX, C. J.; MILLER, H. T. Modern / postmodern Public Administration: a discourse about what is real. Administrative Theory \& Praxis v. 18, n. 1, p. 41, 1996.

FOUCAULT, M. Discipline and punish. Harmondsworth : Penguin, 1979.

GEIS, D. R. Postmodern theatric(k)s: monologue in contemporary American drama. Ann Arbor : University of Michigan Press, 1993.

HARMON, M. M. Responsibility as paradox: a critique of rational discourse on government. Londres: Sage, 1995.

HARMON, M. M. On the futility of universalism. Administrative Theory $\&$ Praxis, v. 18, n. 2, p. 74-83, 1997

HERNANDEZ, J. P. In Atlixco late night meeting with reporter Hadden, Gerry, aired on NPR program All things considered, 20 abr. 2001 (tape). Disponivel em: <http://www.npr.org/ramfiles/atc/20010420.atc.03.rmm>.

HUMMEL, R P. Post-Modernism and a Reasonable Philosophy. Administrative Theory and Practice. v. 18 n.l.

IL MANIFESTO. Story about Italian High School tournament shut down due to Nike protest by students. Disponível em: <www.ilmanifesto.it/Quotidiano-archivio/03-Aprile-2001/art34.htm>. Acesso em: 11 abr. 2001.
JON, J. S.; CAMPODONCIO, L. Globalization and democratic governance: a contradiction. Administrative Theory \& Praxis, v. 20, n. 4, p. 78-90, 1998.

KAHLE, L. R.; BOUSH, D. M.; PHELPS, M. Good morning, Vietnam: an ethical analysis of Nike activities in Southeast Asia. Sport Marketing Quarterly. v. 9, n. 1, p. 43- 52, 2000.

KAMEL, R.; HOFFMAN, A. The maquiladora reader: cross-border organizing since NAFTA. Philadelphia: American Friends Service Committee, 1999.

KAPLAN, C. For their civil disobedience, the 'sit-in' is virtual. Cyberlaw Journal. New York Times on the Web. 1 maio 1998. Disponível em: <http:/ /www.nytimes.com/library/tech/98/05/cyber/cyberlaw/0llaw.html>.

KING, C. S.; STIVERS, C. Government is us: Public Administration in antigovernment era. Londres: Sage, 1998.

KRISTEVA, J. Desire in language: a semiotic approach to literature and art. Nova York : Columbia University Press e Londres : Basil Blackwell, 1980(a).

KRISTEVA, J. Word, dialogue, and novel. Desire and Language. Nova York: Columbia University Press, 1980b. p. 64-91.

KRISTEVA, J. Word, dialogue, and the novel. In: MOI, T. (Ed.). The Kristeva reader. Nova York: Columbia University Press, 1986. p. 35-61.

LEWIS, S. The grassroots environmental experience on devolution and decentralized action. (Working paper). Enviroweb, 22 fev. 1998. Forthcoming, Boston Review. Disponível em: <http://www.enviroweb.org/ gnp/devolution.htm> Lista de referência em: <http://www.min.net/ kala/ fed/manbib.htm>. Acesso em: 16 jan. 1999.

MACADAM, M. Working for the rat. New Internationalist Magazine (online), dez. 1998. Disponivel em: <http://www.thirdworldtraveler.com/ Global_Secrets_Lies/WorkingForRAt_DisneyHaiti.html>.

MAQUILADORA SOLIDARITY NETWORK. Designing your own sweatshop fashion show (200la). Disponivel em: <http:// www.maquilasolidarity.org/tools/campaign/fashionshow.htm>.

MAQUILADORA SOLIDARITY NETWORK. Who's who in WRAP? $6 \mathrm{abr}$. 2001(b). Disponível em: <ll "WRAP" http://www.maquilasolidarity.org/ resources/codes/memo6.htm\#WRAP>.

MACALOON, J. J. Olympic games and the theory of spectacle in modern societies. In: MACALOON, J. J. (Ed.). Rite, Drama, Festival, Spectacle: rehearsals toward a theory of cultural performance. Philadelphia : Institute for the Study of Human Issues, 1984. p. 241-80.

MARSHALL, G. S.; WHITE, O. F. The Blacksburg manifesto and the postmodern debate: Public Administration in a time without a name. American Review of Public Administration, v. 20, n. 2, p. 61-76, 1990.

MARX, Karl. Capital: A Critical Analysis of Capitalist Production. Translated from the third German edition, by Samuel Moore and Edward Aveling, and edited by Frederick Engels. London: Swann Sonnenschein, Lowrey \& Co., 1867.

MSSWAIN, C.; WHITE, O. F. A transformational theory of organizations. American Review of Public Administration, v. 23, n. 2, p. 81-98, 1993. 
MCSWITE, O. C. On the proper relation of the theory community to the mainstream Public Administration community. Administrative Theory \& Praxis, v. 21, n. 1, p. 4.

MCSWITE, O. C. Legitimacy in Public Administration: a discourse analysis. (Advances in Public Administration, Vol. 4). Thousand Oaks : Sage, 1997 (a).

MCSWITE, O. C. Jacques Lacan and the theory of the human subject: how psychoanalysis can help Public Administration. American Behavioral Scientist, v. 4l, p. 43-63, 1997 (b).

MCSWITE, O. C. Postmodernism, Public Administration, and the public interest. In: WAMSLEY, G. L.; WOLF, J. F. (eds.). Refounding democratic Public Administration: modern paradoxes, postmodern challenges. Thousand Oaks : Sage, 1996.

MCSWITE, O. C. Legitimacy in Public Administration: a discourse analysis. Londres : Sage, 1997 (c).

MCSWITE, O. C. The new normativism and the discourse movement. Administrative Theory \& Praxis, v. 20, n. 3, p. 377-81, 1998.

MCSWITE, O.C. Skepticism, doubt, and the real: a gesture toward intellectual community and a new identity for Public Administration. Administrative Theory \& Praxis, v. 18, n. 1, p. 109.

MCSWITE, O.C. Postmodern theory and the paradoxes of modernism. Administrative Theory \& Praxis, v. 18, n. 1, p. 69.

MCSWITE, O.C. On the necessity of admitting the idea of the unconscious into any post-rational model of Public Administration. Administrative Theory E Praxis, v. 18, p. 1, p. 51.

MILLER, H. T.; FOX, C. J. Postmodernism, "reality" \& Public Administration: a discourse. Burke: Chatelaine Press, 1997.

MORGAN, D. Institutional survival in the postmodern age: administrative practice and the American constitutional legacy. Administrative Theory $\&$ Praxis, v. 18 , n. 2, p. 42-56, 1996

MUELLER, N. Discovering the carnivalesque: a project for tracing the carnivalesque. (Web page). Disponível em: <http://www.sas.upenn.edu/ nnueller/grmn247/carnival.html>. Acesso em: 25 nov. 2000.

NATIONAL LABOR RELATIONS. Cutler corporation, a Disney subcontractor pulled production out of Haiti after bad press to relocate 2,000 jobs to China (1997). Disponível em: <http://www.nlcnet.org/ disney>. Acesso em: 12 set. 2000

O'ROURKE, D. Monitoring the monitors: a critique of PricewaterhouseCoopers ( $\mathrm{PwC}$ ) labor monitoring. (Unpublished paper). 28 set. 2000, MIT. Disponível em: <http://web.mit.edu/dorourke/www/ $\mathrm{PDF} /$ pwc.pdf>

PEREIRA, J. Apparel Makers Back New Labor Inspection Group. The Wall Street Journal. 04/10/2001. http://www.studorg.nwu.edu/peace/ wsj4_10_01. <http://www.studorg.nwu.edu/peace/wsj4_10_01.html> html <http://www.studorg.nwu.edu/peace/wsj4_10_01.html>.
POSNAU, P. M. Post-modernism and the social sciences: insights, in-roads, and intrusions. New Jersey : Princeton University Press, 1992.

RIMMERMAN, C. A. The new citizenship: unconventional politics, activism, and service. Boulder : Westview Press, 1997.

ROBERTS, D.; BERNSTEIN, A. A life of fines and beating. Business Week, p. 123-8, 2 out. 2000.

SANER, R. Organizational consulting: what a gestalt approach can learn from off-off-Broadway theater. Gestalt Review, v. 3, n. 1, p. 6-34, 1999.

SCHWARTZ, E. A. Netactivism: how citizens use the Internet. Sebastopol : Songline Studios, 1996

STABILE, C. A. Nike, social responsibility, and the hidden abode of production. Critical Studies in Media Communication, v. 17, p. 2, p. 186204, 2000.

SWEATGEAR designer attire from old-fashioned sweatshops in El Salvador (2001). Disponível em: <http://www.blank.org/sweatgear/line.html>.

UCM. Cruel treatment working for Nike in Indonesia. Report prepared by Urban Community Mission (UCM), dez. 1999. Disponível em: <http:// summersault.com/ agj/clr/alerts/letters/survey.rtf>. Acesso em 9 mar. 2001.

VENTRISS, C. Swimming against the tide: reflections on some recent theoretical approaches of Public Administration theory. Administrative Theory \& Praxis, v. 20, n. 1, p. 91-101, 1998.

VERITÉ Comprehensive factory evaluation report on Kukdong International Mexico, S. A. De C. V. Atlixco, Puebla, Mexico, (data de auditoria: 5-7 fev. 2001). Disponível em: <http://nikebiz.com/media/ nike_verite_report.pdf> (22 pages) e Verité homepage <http:// www.verite.org/>

WEINBERG, B. World Bank / IMF protests rock DC: police spin control masks escalated repression. Radio Free Europe News, 18 abr. 2000. Disponível em: <http://shadow.autono.net/sin001/weinwash2.htm>.

WHITE, O. F; MCSWAIN, C. J. The semiotic way of knowing and Public Administration. Administrative Theory \& Praxis, v. 15, p. 1, p. 18-35, 1993.

YOUNG, A.; HAMILTON, J. The Nike code of conduct report by good works international, 27 jun. 1997. Disponível em: <http:// www.digitalrelease.com/release/goodworks.html>.

ZANETTI, L. A. Advancing praxis: connecting critical theory with practice in Public Administration. American Review of Public Administration v. 27, n. 2, p. 145-167, 1997.

ZANETTI, L. A.; CARR, A.Exaggerating the dialectic: postmodernism's 'new individualism' and the detrimental effects on citizenship. Administrative Theory \& Praxis, v. 21, n. 2, p. 205, 1999.

ZANETTI, L. A.; CARR, A. Putting critical theory to work: diving the public administrator the critical edge. Administrative Theory \& Praxis, v. 19, n. 2, p.208-24, 1997. 